\title{
PENERAPAN MANAJEMEN RISIKO OPERASIONAL PADA UNIT TELLER PT. BANK PEMBANGUNAN DAERAH SUMATERA BARAT
}

\author{
Teti Mulia, Afriyeni \\ Akademi Keuangan dan Perbankan Padang \\ Afriyeni.yen@gmail.com
}

\begin{abstract}
The purpose of this research is to find out how the implementation of operational risk management at the Teller Unit of PT. Bank Pembangunan Daerah Sumatera Barat. Methods of collecting data for this study were collected through interviews with related parties. Data analysis method in this study uses descriptive method with an inductive mindset that explains the results of research on facts that occur in the field which are then analyzed according to existing theories. Based on the results of this study it was found that PT. Bank Pembangunan Daerah Sumatera Barat has implemented operational risk management at the teller unit. This is indicated by the minimum of undesirable events such as the risk of counterfeit money, errors in inputting the nominal and account number at the time of the transaction, the shortfall or excess payment to the customer, the shortfall or excess when receiving the customer's deposit, the risk of incorrect transfer / mutation input.
\end{abstract}

Keyword : management application, operational risk, teller

\section{PENDAHULUAN}

Keberadaan sektor di perbankan merupakan subsistem dalam meningkatkan perekenomian suatu negara, yang mempunyai peranan yang cukup penting bagi kehidupan masyarakat modern saat ini, sehari-hari sebagian besar melibatkan jasa dari sektor perbankan dengan tingkat kepercayaan masyarakat terhadap perbankan terus meningkat ditandai adanya peningkatan dana masyarakat ke sektor perbankan. Bank merupakan badan usaha yang tugasnya menghimpun dana dari masyarakat dalam bentuk simpanan dan menyalurkan kembali kepada masyarakat dalam bentuk kredit untuk meningkatkan taraf hidup ekonomi masyarakat (Abdullah, 2014).

Sedangkan menurut Dahar, (2016) bank merupakan suatu lembaga keuangan yang dalam operasinya mengumpulkan dana dari masyarakat yang memiliki kelebihan dana (surplus spending unit) dan menyalurkan dana tersebut berupa kredit kepada masyarakat yang membutuhkan dana (deficit spending unit).

Dalam bidang pembangunan, pemerintah pada 25 Mei 1960 mendirikan Bank Pembangunan Daerah (BPD) yang ketentuanya diatur dalam UU No. 13/1962. Bank ini didirikan dengan tujuan untuk membantu melaksanakan pembangunan daerah yang merata ke seluruh daerah Indonesia. Bank Pembangunan Daerah memiliki fungsi dan peranan dalam pembangunan ekonomi regional, karena Bank Pembangunan Daerah memiliki pembukaan jaringan pelayanan di daerah-daerah, 
dimana secara ekonomis tidak mungkin dilakukan bank swasta. Sampai saat ini ada 26 BPD di Indonesia, rata-rata setiap provinsi mempunyai satu BPD dan salah satunya adalah di Provinsi Sumatera Barat yang mempuyai Bank Pembangunan Daerah Sumatera Barat dengan sebutan PT. Bank Nagari Sumbar, yang bertujuan khusus untuk melakukan pembantuan dan pendorongan pada pertumbuhan perekonomian dari berbagai bidang serta sebagai salah satu sumber pokok pada pendapatan daerah dalam rangka meningkatkan taraf hidup rakyat banyak.

Melihat perkembangan yang begitu pesat pada PT. Bank Nagari dan ekonomi yang semakin global, maka akan berbanding lurus dengan semakin kompleksnya permasalahan risiko pada Bank Nagari. Hal ini menyebabkan peningkatan tata kelola yang sehat (good governance) serta fungsi identifikasi, pemantauan dan pengendalian risiko yang mutlak diperlukan, maka dari itu PT. Bank Nagari perlu melakukan penerapan manajemen resiko didalam aktivitas kegiatannya dengan secara sistematis dan bersinergi.

Manajemen merupakan proses perencanaan, kepemimpinan dan pengendalian upaya anggota organisasi serta menggunakan semua sumber daya organisai untuk mencapai tujuan yang telah ditetapkan Leviza, (2014). Sedangkan menurut Murni, (2015) manajemen merupakan kegiatan usaha yang dilakukan untuk mencapai suatu tujuan dan mengkoordinasikan kegiatan-kegiatan orang lain.

Menurut Anisa, (2012) manajemen risiko adalah proses identifikasi, pengukuran dan mengatur keuangan sebuah risiko yang merugikan atau mengancam aset dan penghasilan dari sebuah perusahaan yang dapat menimbulkan kerusakan atau kerugian pada perusahaan tersebut.

Risiko operasional yang harus menjadi perhatianatau memiliki pengaruh langsung ialah sumber daya manusia yang berhubungan dengan karyawan yang bekerja disuatu bank, salah satunya adalah teller.

Menurut (Handayani, 2017) Teller adalah tugas dari seseorang pihak bank yang bertugas untuk melayani nasabah atau customer dalam hal transaksi keuangan perbankan kepada semua nasabahnya.

(Amelia, 2017) menyatakan bahwa teller bertanggung jawab atas transaksi tunai terutama atas penerimaan maupun pembayaran uangnya. Petugas-petugas yang berkerja diunit kerja kas dinamakan kasir atau teller yang dipakai oleh kepala kas. Berdasarkan keterampilan prestasi kerja, senioritas masing-masing petugas dan penjabat dilingkungan unit kerja kas dilimpahi tugas dan wewenang yang berbedabeda.

Ada beberapa kelalaian yang dilakukan oleh seorang teller diantaranya yaitu kelalaian dalam memasukkan nomor rekening nasabah, kelalaian dalam memasukkan jumlah nominal uang yang akan didebet, kelalaian dalam memasukkan nomor rekening tujuan transaksi pemindah bukuan, kelalaian dalam memasukkan jumlah nominal biaya pengiriman uang, kelalaian dalam memasukkan jumlah nominal pajak yang dibayarkan dan kelalaian dalam memasukkan nomor rekening tujuan kliring. Oleh sebab itu Bank Pembangunan Daerah Sumbar harus menerapkan manajemen risiko yang lebih baik lagi terutama pada manajemen teller dikarenakan teller merupakan sebagai dasar utama sektor keuangan dalam melakukan pelaksanaan fungsi intermediasi dan pelayanan jasa keuangan, sektor perbankan sangat jelas perlu 
adanya distribusi risiko yang efisien, tingkat efisiensi dalam distribusi risiko akan dapat nantinya menentukan alokasi sumber daya dana diperekonomian. Oleh karena itu pelaku sektor perbankan, dan PT. Bank Pembangunan Daerah Sumatera Barat khususnya dituntut untuk mampu secara efektif mengelola risiko yang dihadapinya.

Penerapan sistem manajemen risiko pada PT. Bank Pembangunan Daerah Sumatera Barat sangat diperlukan, untuk menahan kemungkinan jika terjadinya kerugian akibat risiko maupun memperkuat struktur kelembagaan (Irfan, 2015).

Berdasarkan latar belakang permasalahan di atas, maka penulis tertarik melakukan penelitian dalam bentuk Tugas Akhir dengan judul: "Penerapan Manajemen Risiko Operasional pada Unit Teller PT. Bank Pembangunan Daerah Sumatera Barat".

\section{METODE PENELITIAN}

\section{Metode Pengumpulan Data}

1. Studi Lapangan

Pada penelitian ini dilakukan dengan cara melakukan wawancara dengan pihak-pihak PT. Bank Pembangunan Daerah Sumatera Barat.

2. Studi Kepustakaan

Penelitian ini dilakukan dengan mengumpulkan data dan menggunakan teoriteori yang berkaitan dengan masalah-masalah yang akan dibahas, berupa bukubuku yang berkaitan dengan masalah.

\section{Metode Analisa Data}

Metode analisa data yang digunakan dalam penelitian ini adalah Metode Analisis Kualitatif yang menjelaskan secara deskriptif yaitu dengan menguraikan data secara sistematis dari fakta-fakta yang didapat kemudian dihubungkan dengan Penerapan Manajemen Risiko Operasional pada Unit Teller PT. Bank Pembangunan Daerah Sumatera Barat.

\section{ANALISA DAN PEMBAHASAN}

Gambaran Manajemen Risiko Operasional Pada Unit Teller Bank Pembangunan Daerah Sumatera Barat.

PT. Bank Pembangunan Daerah senantiasa memberikan yang terbaik dan menjadi Bank kebanggan Sumatera Barat yang unggul dalam layanan dan kinerja.

Untuk meningkatkan kualitas SDM yang baik Bank Pembangunan Daerah sangat memperhatikan manajemen risiko operational pada unit teller yang selalu berada di garda depan dalam kegiatan operasional bank menjadikannya selalu berinteraksi dengan nasabah serta dituntut untuk memberikan pelayanan yang maksimal terhadap seluruh nasabah yang datang ke bank.

Menurut Mayangsari,(2016) Teller merupakan tugas seorang petugas bank yang memiliki tugas dalam melayani nasabah melakukan transaksi keuangan kepada semua nasabah.

Teller bertanggung jawab atas transaksi tunai terutama dalam penerimaan maupun pembayaran uangnya, petugas yang bekerja diunit kerja kas disebut dengan kasir atau teller yang dipakai oleh kepala kas. Berdasarkan keterampilan prestasi kerja, senioritas masing-masing petugas dan penjabat dilingkungan unit kerja kas di 
limpahi tugas dan wewenang yang berbeda-beda. Tugas-tugas teller di bedakan menjadi beberapa kelompok antara lain yang berhubungan dengan:

1. Persediaan uang tunai

Bank memelihara persediaan uang tunai dalam berbagai macam jenis persediaan, yang dapat dibedakan menjadi 2 golongan yaitu persediaan umum yang menjadi tanggung jawab kepala teller dibawah pengendaliaan kepala bagian operasional dan persediaan yang disimpan dalam kontak kasir (teller).

2. Penerimaan setoran

Sumber utama persediaan uang tunai merupakan penerimaan setoran melalui nasabah apabila terjadi suatu kekurangan atau melewati batas minimum persediaan bank harus menarik dari bank indonesia atau bank lain.

a. Pembayaran uang tunai

Persedian uang tunai oleh bank disalurkan melalui pembayaran tunai kepada nasabah dan pembayaran tunai lain. Setiap teller melakukan pembayaran tunai sesuai dengan limit atau tingkat kewenangannya masing-masing.

Proses Identifikasi, Pengukuran, Pemantauan dan Sistem Informasi Manajemen Risiko Operasional Unit Teller Pada PT. Bank Pembangunan Daerah Sumatera Barat.

1. Identifikasi Risiko Operasional

a. Bank Pembangunan Daerah (BPD) Sumatera Barat melakukan identifikasi dan analisa terhadap faktor penyebab timbulnya risiko operasional yang melekat pada seluruh aktivitas fungsional, produk, proses dan sistem informasi, baik yang disebabkan oleh faktor intern maupun ekstern yang berdampak negatif terhadap pencapaian sasaran organisasi bank.

b. Bank BPD Sumbar memiliki prosedur penilaian yang memadai terhadap risiko operasional yang melekat pada aktivitas dan produk baru termasuk proses dan sistemnya.

c. Hasil identifikasi tersebut selanjutnya digunakan untuk mengembangkan suatu database mengenai jenis kerugian (liss events) yang ditimbulkan oleh risiko operasional.

d. Metode yang dapat digunakan oleh Bank BPD Sumatera untuk mengidentifikasi risiko operasional, antara lain :

e. Self risk assessment berupa checklist untuk mengidentifikasi kekuatan dan kelemahan pada lingkungan risiko operasional bank, seperti peranan Komisaris dan Direksi, struktur organisasi, sumber daya manusia, serta arus informasi dan komunikasi pada bank.

f. Risk mapping berupa pemetaan menurut jenis risiko terhadap aktivitas fungsional, struktur organisasi dan proses transaksi.

g. Key risk indicators berupa statistik atau matriks yang menyediakan data posisi risiko operasional bank, seperti jumlah pembatalan transaksi, tingkat perputaran pegawai, dan frekuensi kesalahan (errors).

h. Scorecards yang menyediakan metode untuk mentranslasikan penilaian/kriteria kualitatif menjadi matriks kuantitatif, yang dapat digunakan untuk mengalokasikan kebutuhan moral masing-masing aktivitas fungsional.

i. Pengukuran Risiko Operasional 
1) Setelah Bank BPD Sumatera Barat melakukan identifikasi risiko operasional yang melekat pada aktivitas fungsional tertentu, Bank BPD Sumbar menilai parameter yang mempengaruhi risiko operasional, antara lain jumlah dan frekuensi :

a) Kegagalan dan kesalahan sistem;

b) Sistem administrasi;

c) Kegagalan hubungan dengan nasabah;

d) Accounting error;

e) Penundaan dan kesalahan penyelesaian pembayaran;

f) Fraund;

g) Rekayasa akunting;

h) Strategic failure.

i) Pengumpulan Data Risiko Operasional

j. Sumber yang menjadi utama pada penerapan manajemen risiko operasional ialah data - data yang memiliki historis tentang kerugian pada bank yang disebabkan risiko operasional yang sudah divalidasi dan diverifikasi.

k. Data kerugian risiko operasional terdiri dari kejadian (events) yang sifatnya rutin, berfrekuensi tinggi namun sangat berdampak rendah maupun berfrekuensi rendah namun memiliki berdampak tinggi pada rugi laba bank. Data kerugian tersebut bersifat :

1) Dapat diprediksi (expected) seperti events yang memiliki frekuensi yang tinggi namun berdampak rendah.

2) Sulit diprediksi (unexpected) seperti events yang memiliki frekuensi rendah namun berdampak tinggi.

3) Bank BPD Sumbar mencatat dan menatausahakan setiap events termasuk jumlah potensi kerugian yang diakibatkan events dimaksud dalam suatu administrasi data. Pencatatan dan penatausahaan data tersebut disusun dalam suatu bentuk data statistik yang dapat digunakan untuk memproyeksi potensi kerugian pada suatu periode dan aktivitas fungsional tertentu.

4) Pemantauan Risiko Operasional

5) Bank BPD Sumbar melakukan pemantauan risiko operasional berkelanjutan kepada seluruh eksposur risiko operasional serta kerugian (loss events) yang menimbulkan pada aktivitas fungsional utama (major business line), antara lain melalui cara penerapan sistem pengendalian intern dan menyediakan laporan - laporan berkala tentang kerugian yang ditimbulkan oleh risiko operasional.

6) Bank BPD Sumbar melakukan review secara berkala terhadap faktor-faktor penyebab timbulnya risiko operasional serta dampak kerugiannya.

7) Satuan kerja manajemen risiko harus menyusun laporan keuangan mengenai kerugian dari risiko operasional dan hasil review kepatuhan audit intern serta penyampaian laporan tersebut kepada Komite Manajemen Risiko dan Direksi.

8) Sistem Informasi Manajemen Risiko Operasional

9) Bank BPD Sumbar memiliki sistem dan teknologi informasi yang memadai, sesuai dengan sifat dan volume transaksi. 
10) Sistem informasi manajemen harus bisa menghasilkan sebuah laporan laporan yang sangat lengkap dan akurat yang digunakan untuk pemantauan risiko dalam rangka mendeteksi dan mengoreksi penyimpangan secara tepat waktu guna mengurangi potensi terjadinyan loss events.

11) Sistem informasi manajemen harus dapat menyediakan laporan eksposur risiko operasional lengkap, akurat dan tepat waktu dalam rangka suatu proses pengambilan keputusan oleh Direksi.

\section{Pengendalian Risiko Operasional Unit Teller Pada PT. BankPembangunan Sumatera Barat.}

Contoh kasus yang berkaitan dengan pengendalian risiko operasional unit teller pada PT. BPD Sumbar yaitu kasus pencatatan pembukuan pada sistem yang tidak memiliki kesamaan dari uang secara fisik, yang disebabkan oleh kelalaian teller pada PT. BPD Sumbar yangsalah menginput setoran tunai,yang mengakibatkan perbedaan uang secara fisik dengan pencatatan pembukuan pada sistem menjadi berbeda yang baru diketahui pada penutupan transaksi pada sore harinya, maka harus diselesaikan pada hari yang sama.

Adapun tata cara penyelesaian selisih kas diteler ialah sebagai berikut:

1. Apabila terjadi selisih kasus kas baik selisih kurang atau lebih teller wajib menginformasikan kepada kepala bagian operasional dan/atau direktur operasional.

2. Jika terjadi selisih kurang yang penyebabnya oleh kelalaian atau kekeliruan teller, ketika penarikan atau penyetoran dari nasabah yang tidak dapat ditagih kembali kepada nasabah, maka teller berkewajiban mengganti pada saat hari yang sama.

3. Jika terjadi selisih kas lebih jangan diamankan atau disimpan dalam bentuk tunai dimasukan kedalam amplop oleh pihak bank atau dikuasai sendiri oleh teller dengan asumsi dana cadangan untuk dilakukan kompensir, apabila sewaktu-waktu terjadi selisih kurang.

4. Selisih kas lebih yang disebabkan adanya pembulatan pembayaran atau penyetoran agar disetorkan ke pendapatan non operasional bank (laba/rugi).

5. Apabila terjadi selisih kas lebih yang tidak dapat ditaksirkan penyebabnya pada hari yang sama agar dibukukan (posting) ke rekening perantara (misalnya rekening penampungan sementara atau penampungan selisih kas) dengan membuat berita acara selisih kas lebih.

6. Bila mana penyebab selisih kas lebih tidak ditemukan (misalnya salah buku atau komplain dari nasabah) sampai dengan jangka waktu tertentu (misalnya 1 bulan) maka dapat dihapus buku dengan memindahkan nominal selisih kas lebih kependapatan non operasional (laba/rugi) setelah mendapat persetujuan dari direktur utama.

7. Penyelesaian selisih kas lebih harus diselesaikan secara kasus per kasus dan tidak boleh dilakukan potong tambah (kompensasi) dengan selisih kas pada hari lain.

8. Perlakuan akuntansi (accounting treatment) terhadap selisih kas lebih dengan jurnal pembukuan.

Sehingga dalam kasus ini penyelesaian yang dilakukan oleh teller melaporkan kepada manager teller, sehingga manager teller memberikan solusi kepada teller mengganti dengan uang pribadi teller yang salah mengimput data setoran tunai 
karena pada sistem tidak bisa diubah apabila sudah diimput, sehingga teller mengganti uang yang kurang dengan uang pribadinya.

Oleh sebab itu manager unit teller harus memastikan bahwa PT. Bank Pembangunan Daerah Sumbar telah memiliki kebijakan dan prosedur pengendalian dan mitigasi risiko operasional yang dipatuhi dan dilaksanakan oleh unit teller, agar tidak timbulnya kasus yang serupa seperti kasus diatas.

Hal-hal yang harus dilakukan oleh PT. Bank Pembangunan Daerah Sumbar agar tidak terjadinya kasus yang berhubungan pada operasional unit teller :

1. Bank Pembangunan Daerah Sumatera Barat memiliki kebijakan, prosedur dan proses untuk mengendalikan atau memitigasi risiko operasional, sesuai dengan kompleksitas operasional bank.

2. Dalam penerapan pengendalian risiko operasional, Bank Pembangunan Daerah Sumatera Barat mengembangkan program untuk memitigasi risiko operasional antara lain pengamanan proses teknologi informasi, asuransi, dan outsourcing sebagian kegiatan operasional Bank.

3. Bank Pembangunan Daerah Sumatera Barat memiliki support system, yang sekurang-kurangnya mencakup:

a. Identifikasi error secara dini

b. Pemprosesan dan penyelesaian seluruh transaksi secara efisien, akurat dan tepat waktu

c. Kerahasiaan, kebenaran serta keamanan transaksi

4. Bank Pembangunan Daerah Sumatera Barat melakukan kaji ulang secara berkala terhadap prosedur, dokumentasi, sistem pemrosesan data, contigency plan, dan praktek operasional lainnya guna mengurangi kemungkinan terjadinya kesalahan manusia (human error) yang menimbulkan risiko operasional.

Potensi Risiko Operasional Unit Teller Pada PT. Bank Pembangunan Daerah Sumatera Barat.

Unit Teller pada PT. BPD Sumbar mempunyai potensi risiko operasional yang tinggi karena berhubungan langsung dengan materi dalam uang tunai, kesalahan yang sering terjadi pada risiko operasional unit teller pada PT. BPD Sumbar yaitu kesalahan dalam pengimputan data.

Beberapa potensi risiko yang dapat terjadi pada unit Teller PT. BPD Sumbar meliputi :

1. Risiko adanya uang palsu.

2. Kesalahan dalam penginputan nominal dan nomor rekening pada saat transaksi.

3. Kekurangan atau kelebihan bayar kepada nasabah.

4. Kekurangan atau kelebihan pada saat menerima setoran nasabah.

5. Risiko terjadinya salah pemindahbukuan / input mutasi.

Oleh sebab itu PT. Bank Pembangunan daerah Sumbar memiliki kebijakan dan prosedur pengendalian dan mitigasi risiko operasional yang dipatuhi dan dilaksanakan oleh unit teller PT. BPD Sumbar.

Prosedur Manajemen Risiko Operasional Unit TellerPada PT. Bank Pembangunan Daerah Sumatera Barat

Pada prakteknya prosedur Manajemen Risiko Operasional pada unit teller dapat dilihat pada aktifitas harian yang dilakukan dengan berpedoman pada sistem dan 
prosedur yang telah ditetapkan, namun PT. Bank Pembangunan Daerah Sumatera Barat menggunakan prosedur manajemen risiko operasional pada unit teller dilakukan dengan mengikuti sistem dan prosedur yang telah ditetapkan oleh pihak manajemen, prosedur manajemen risiko operasional ini dilakukan untuk menghindari terjadinya risiko selisih pada kas.

Dimulai pada pagi hari dimana manager teller yang mendapat wewenang untuk masuk khasanah akan melakukan serah terima cashbox kepada masing-masing teller yang bertanggung jawab sepenuhnya atas isi masing-masing cashbox. Isi Cashbox tersebut, yaitu : uang tunai pecahan kecil yang tidak dapat disetorkan kepada head teller pada akhir hari sebelumnya.

Selanjutnya teller akan siap memulai aktivitas hariannya antara lain :

1. Menerima Setoran Tunai

Langkah-langkah yang dilakukan oleh teller, yaitu :

a. Menerima uang tunai dan slip setoran dari nasabah, lalu menghitung jumlah uang dan mencocokkan jumlah fisik uang tersebut dengan angka yang tertera pada slip setoran.

b. Kemudian teller akan menghitung uang baik dengan menggunakan mesin hitung uang maupun secara manual lalu memeriksa keaslian uang tersebut dengan menggunakan lampu UV.

c. Mencocokkan penulisan angka dan terbilang pada slip setoran, serta memverifikasi tanda tangan nasabah. Memastikan nomor rekening yang tertera pada slip setoran cocok dengan nama nasabah pada sistem komputer.

d. Jika sudah cocok, teller akan memposting slip setoran, dan memastikan nama yang tertera di system sama dengan nama yang tertera pada slip setoran.

e. Menerima Penarikan Tunai

Langkah-langkah yang dilakukan :

1) Memverifikasi tanda tangan pada slip penarikan untuk memastikan tanda tangan tersebut sama dengan yang tertera pada specimen buku tabungan untuk memastikan yang melakukan penarikan uang adalah sipemilik rekening.

2) Memeriksa penulisan angka dan terbilang.

3) Memposting dan memastikan bahwa nasabah tersebut mempunyai saldo diatas saldo minimum.

4) Membayarkan uang yang ditarik dan melakukan penghitungan di depan nasabah tersebut untuk menghindari kecurangan baik oleh teller maupun pihak nasabah.

f. Melakukan Transfer Uang

Langkah-langkah yang dilakukan :

1) Menerima slip transfer dari nasabah, memeriksa nominal dan terbilang.

2) Memverifikasi tanda tangan nasabah apabila penarikan dilakukan secara debet rekening, dan memastikan kebenaran nomor rekening dan nama. Jika dilakukan secara tunai, menghitung uang dan mencocokkan jumlah fisik uang dengan nominal yang tertera pada slip transfer. Proses lainnya sama dengan penerimaan setoran tunai. Setelah uang yang diterima "klop", teller akan mempostingkan jumlah uang yang akan ditransfer atau pindah bukukan 
jika debet rekening termasuk biaya pada sistem, lalu mengekspedisikan slip transfer ke bagian / unit yang terkait.

g. Menerima Penukaran Mata Uang Asing.

Terhadap penukaran mata uang asing, teller akan memeriksa tahun dan seri penerbitan uang tersebut, memeriksa keasliannya dengan menggunakan lampu UV, dan mempostingnya ke dalam sistem komputer.

Pada sore hari, masing-masing teller akan melakukan "balancing", jika sudah "klop" masing-masing teller akan menyetorkan uang tunainya kepada head teller. Tidak semua uang tunai dapat disetorkan ke head teller, teller hanya dapat menyetorkan setiap pecahan mata uang dengan jumlah minimum 100 lembar dan kelipatannya atau 1 ikat tiap pecahan. Kemudian ia harus memastikan bahwa saldo kas yang tersisa secara fisik dalam cashbox adalah sama dengan saldo kas secara sistem.

\section{Antisipasi yang dilakukan Bank Pembangunan Daerah Sumatera Barat}

Dalam mengantisipasi kerugian yang mungkin timbul dari risiko operasional, Bank Pembangunan Daerah Sumatera Barattelah melakukan beberapa tindakan antisipatif yang meliputi :

1. Sandi (password)

Masing-masing user memiliki password yang digunakan untuk masuk dan "login" pada sistem yang akan digunakan untuk menjalankan kegiatan operasional sehari-hari. Password ini akan habis masa berlakunya dalam jangka waktu empat belas hari. Untuk itu user wajib mengganti password tersebut sebelum habis masa berlakunya. Hal ini sangat membantu pengendalian terhadap risiko penyalahgunaan password.

2. Pemisahan Wewenang dan Tanggung Jawab

Terdapat beberapa pemisahan wewenang dan tanggung jawab dalam hal :

a. Pemegang kunci dan kode kombinasi khasanah, di mana :

1) Authorized Signer memegang kunci brankas uang.

2) Supervisor memegang kunci pintu besi luar dan teralis

3) Manager Operasional memegang kode kombinasi pintu besi luar dan kode kombinasi brankas uang.

b. Pemegang kunci dan kode kombinasi ruang Safe Deposit Box, di mana :

1) Customer Service memegang kunci master box.

2) Head CS memegang kunci pintu teralis dalam.

3) Supervisor memegang kunci pintu besi luar.

4) Manager Operasional memegang kode kombinasi pintu besi luar.

c. Pemegang kunci dan kode kombinasi mesin ATM, di mana :

1) Head teller memegang kunci pintu brankas ATM.

2) Supervisor memegang kode kombinasi pintu brankas ATM.

Hal ini dilakukan dengan maksud agar terdapat dual control dan memperkecil kemungkinan terjadinya penyalah-gunaan wewenang dan tanggung jawab.

\section{SIMPULAN}

1. Kegiatan operasional merupakan kegiatan yang tidak dapat dipisahkan dari sebuah perusahaan, karena tanpa kegiatan ini sebuah perusahaan tidak akan dapat 
menjalankan aktivitasnya, sehingga peran manajemen risiko semakin diperlukan, karena baik bank maupun pengawas bank diseluruh dunia, semakin menyadari bahwa praktik manajemen risiko yang baik harus dilakukan, tidak hanya untuk keberhasilan suatu bank saja, namun juga untuk sistem perbankan secara keseluruhan.

2. Unit Teller mempunyai potensi risiko operasional yang tinggi karena berhubungan langsung dengan materi dalam hal ini uang tunai. Kesalahan yang terjadi akan berakibat fatal terhadap jumlah uang tunai di khasanah dan juga neraca.

Beberapa potensi risiko yang dapat terjadi pada unit Teller meliputi :

a. Risiko adanya uang palsu.

b. Kesalahan dalam penginputan nominal dan nomor rekening pada saat transaksi.

c. Kekurangan atau kelebihan bayar kepada nasabah.

d. Kekurangan atau kelebihan pada saat menerima setoran nasabah.

e. Risiko terjadinya salah pemindahbukuan / input mutasi.

3. Kebijaksanaan kantor pusat PT. Bank Pembangunan Daerah Sumatera Barat yang terus beradaptasi dengan situasi lingkungan terkini dan terus menerus memberikan informasi dan petunjuk kepada bidang-bidang yang melakukan kegiatan operasional merupakan langkah strategis untuk mempertahankan kelangsungan hidup perusahaan dengan menekan tingkat risiko operasional sehingga biaya (cost) yang ditimbulkan dari risiko ini dapat diminimalkan.

4. PT. Bank Pembangunan Daerah Sumatera Barat menggunakan prosedur manajemen risiko operasional pada unit teller dilakukan dengan mengikuti sistem dan prosedur yang telah ditetapkan oleh pihak manajemen, prosedur manajemen risiko operasional ini dilakukan untuk menghindari terjadinya risiko selisih pada kas

\section{UCAPAN TERIMA KASIH}

Penulis ucapkan puji dan syukur atas kehadirat-NYA, yang telah melimpahkan rahmat, hidayah kepada saya. Penulis ingin menyampaikan terima kasih yang tak terhingga atas bimbingan Ibuk Afriyeni, SE.MM yang telah memberikan motivasi, masukan - masukan maupun terima kasih untuk semangat dan dukungannya yang sangat berguna untuk Tugas Akhir. Akhir kata penulis ucapkan terima kasih, semoga apa yang penulis tuangkan dalam karya kecil ini memberikan manfaat terutama bagi saya sendiri selaku penulis. Amin ya Rabbal'alamin.

\section{DAFTAR PUSTAKA}

Abdullah, Thamrin. 2014. buku Lembaga Keuangan Pengertian Dan Sejarah Singkat Perbankan Di Indonesia.

Amelia, Tri Rezeki. 2017. "Tinjauan Sevice Excellent Teller Pada Bank Nagari Siteba." In Sripsi Kementerian Riset, Teknologi Dan Pendidikan Tinggi Politeknik Negeri Padang, , 6-7.

Anisa, Windi Gessy. 2012. “Analisis Faktor Yang Mempengaruhi Pengungkapan 
Manajemen Risiko." Skripsi Fakultas Ekonomika Dan Bisnis Universitas Diponegoro Semarang: 22.

Dahar, Reni. 2016. “Analisis Tingkat Kesehatan Bank Dengan Menggunakan Model Risk-Based Bank Rating (Rbbr) (Studi Pada Perbankan Yang Listing Di Bursa Efek Indonesia Periode 2011-2014).” Jurnal Menara ilmu X(73): 12.

Grace, Diana. 2017. “Analisis Pengaruh Automatic Teller Machine Dan Short Message Service Banking Terhadap Kepuasan Nasabah.” Jurnal Elektronik Sistem Informasi dan Komputer 3(1): 39-50.

Hanafi, Mamduh M. 2014. "Risiko, Proses Manajemen Risiko, Dan Enterprise Risk Management.” In Book Manajemen Risiko, , 1-40.

Handayani, Putri Rizki. 2017. "Peningkatan Kualitas Layanan Teller Guna Mencapai Kepuasan Nasabah Pada PT Bank Rakyat Indonesia (Persero) Tbk, Unit Teluk Dalam Banjarmasin Novi." I: 31-32.

Irfan, Andi. 2015. "Penerapan Dan Pengelolaan Manajemen Resiko (Risk) Dalam Industri Perbankan Syariah: Studi Pada Bank BUMN Dan Bank Non BUMN." : 38-45.

Leviza, Jelly. 2014. "Peranan Manajemen Risiko Dalam Tugas Dan Tanggung Jawab Direksi Bank Berdasarkan Peraturan Perundang-Undangan Di Indonesia." jurnal USU Law Journal, Vol.II-No.1 1(1): 22-25.

Mayangsari, Yashinta. 2016. "Sistem Antrian Teller Bank Mandiri Sebagai Upaya Meningkatkan Efisiensi Kecepatan TransaksI." Jurnal Ekonpomi \& Bisnis 1: 11.

Murni, Sri. 2015. "Penerapan Manajemen Risiko Untuk Meminimalisir Risiko Kredit.” Jurnal EMBA Penerapan Manajemen Risiko 3(4): 34-46.

Safitri, R. N., \& Marlius, D. (2017). Penerapan E-Banking Dalam Meningkatkan Jasa Dan Layanan Perbankan Di PT. Bank Rakyat Indonesia Cabang Padang. https://doi.org/10.31227/osf.io/gkv8t

Wulandari, R., \& Susanto, R. (2019). Penerapan Manajemen Risiko Operasional Pada Unit Teller Pada PT. Bank Pembangunan Daerah Sumatera Barat Cabang Lubuk Alung. https://doi.org/10.31219/osf.io/pjgch 